\section{Finding common ground: Defining agricultural viability and streamlining multi-organization data collection}

\author{
Libby Christensen a * \\ Colorado State University
}

Learner Limbach $b$

San Juan County Agricultural Resources Committee and Orcas Food Co-op

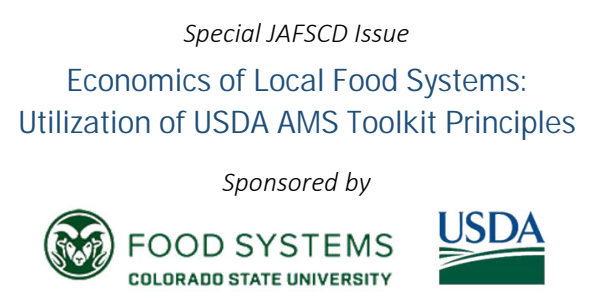

Special JAFSCD Issue

LORADO STATE UNIVERSITY

Submitted April 6, 2018 / Revised July 20, September 18, and O ctober 2, 2018 / Accepted O ctober 2, 2018 /

Published online January 2, 2019

Citation: Christensen, L, \& Limbach, L. (2019). Finding common ground: D efining agricultural viability

and streamlining multi-organization data collection. Journal of A griculture, Food Systems, and Community

D evelopment, 8(Suppl. 3), 137-152. https:/ / doi.org/ 10.5304/ jafscd.2019.08C.005

Copyright @ 2019 by the Authors. Published by the Lyson Center for Civic Agriculture and Food Systems. Open access under CC BY license.

\begin{abstract}
In 2011, the state of Washington created the Voluntary Stewardship Program (VSP), a collaborative and incentive-based approach to land-use management with the goal of protecting critical areas while maintaining and improving the viability of agriculture. Agricultural viability is an attractive ideal supported by a variety of stakeholder groups. Narrowly defined, agricultural viability is the ability of a farmer or a group of farmers to maintain an economically viable farm business. Y et, many feel this definition does not go far enough to reflect the long-term viability of agriculture in a community. It

\footnotetext{
a * C orresponding author: Libby Christensen, Postdoctoral

Research Fellow, Colorado State University.

Christensen is now Extension Agent, Routt County

Colorado State University Cooperative Extension; $1366^{\text {th }}$

Street; Steamboat Springs, CO 80477 USA; +1-970-879-0825;

lchristensen@co.routt.co.us

b Learner Limbach, General Manager, Orcas Food Co-op; 138

North Beach Road; Eastsound, WA 98245 USA;

learner@ orcasfood.coop
}

is, however, difficult to develop a broader shared definition and strategies to evaluate successful implementation of programs to achieve viability across multiple organizations. This paper explores how one county in Washington state organized a multistakeholder engagement process, employing the U.S. D epartment of Agriculture (USD A) Agricultural and Marketing Service (AMS) Toolkit (Thilmany McFadden et al., 2016) to define and measure agricultural viability. The process included collaborative design and implementation of an agricultural viability survey in San Juan County, Washington. We frame our reflective piece within

\footnotetext{
Disclosures

Learner Limbach serves as the chair of the San Juan County Agricultural Resource Committee. At the time of data collection, Libby Christensen was a postdoctoral research fellow at Colorado State University (CSU) and received support from the USD A Economics of Local Food Systems Toolkit team at CSU. The results of this study did not provide either of the authors with any monetary gain, and there were no other conflicts of interest.
} 
the literature on agricultural viability and multistakeholder engagement literature. To conclude, we reflect on the unique features of a multistakeholder working group and the implications for improving the viability of agriculture at the county level.

\section{Keywords}

Agriculture, Viability, Farmland Preservation, Rural-Urban Linkages, USDA Local Food Systems Toolkit

\section{Introduction}

Agriculture underlies the rural economy of San Juan County (SJC), Washington. Over the last 35 years, the number of farms and farmers, as well as farm revenue, has steadily increased in part due to a thriving tourist economy from surrounding urban centers and beyond. D espite this rise, local agricultural products account for only $2 \%$ of the total food market (San Juan County Food Hub Project Team, 2016). Additionally, growth in local agricultural production continues to face a number of challenges, including geographic isolation, high production costs, lack of available infrastructure and access to reliable markets, seasonal drought, and an aging farmer population (San Juan County Voluntary Stewardship Program, 2018). These challenges prompt many to worry about the continued viability of agriculture in SJC. Narrowly defined, agricultural viability is the ability of a farmer or a group of farmers to maintain an economically viable farm business. Y et many feel this definition does not go far enough to reflect the complex set of conditions and attributes associated with a thriving agricultural community.

O rganizations involved in agricultural viability programs have different missions and capacities, which influence their approach to defining and measuring agricultural viability. Figuring out how these new programs fit into existing programs and do not compete for limited resources or create programmatic redundancies is a real challenge. Using an example from Washington State, we present how a group of stakeholder organizations covering the entire food system supply chain, from land access to food sales, came together to create a shared definition of viability. Together the group was also able to develop metrics to evaluate the successful implementation of individual programs as well as the collective impact of its work at the county scale. The organizations used the U.S. D epartment of Agriculture, Agricultural Marketing Service (USD A AMS) Toolkit (Toolkit) (Thilmany McFadden, 2016) to frame this process. The Toolkit was created to guide and enhance the capacity of local organizations to make more deliberate and credible measurements of local and small-scale economic activity and other benefits. It is made up of seven modules. The first set of modules guides early stages of framing local food assessments, including collecting and analyzing relevant primary and secondary data. The process in SJC utilizes this first set of modules.

While SJC is unique with regard to its geography and history, the process outlined below will be familiar to any community with a growing number of organizations- both traditional and nontraditional- looking to address challenges associated with their regional food system. Coordinating efforts can be exceedingly difficult, but can have three major benefits: (1) improved collaboration, (2) enhanced resource investments, and (3) critical alignment to reduce organizational inefficiencies (Jablonski, Angelo, Fox, Christensen, \& Thilmany McFadden, in press).

It is important to note this community-led discussion regarding the appropriate definition of agricultural viability and the development of realistic measurable metrics is eerily similar to efforts to define and measure sustainability with regard to food systems (Hansen, 1996; Kloppenburg, Lezberg, De Master, Stevenson, \& Hendrickson, 2000). Illustrating this point, it is hard to distinguish between sustainability and agricultural viability, as defined by the Washington State Conversation Commission. This definition of agricultural viability is the ability of a farmer or group of farmers to:

- Productively farm on a given piece of land or in a specific area,

- Maintain an economically viable farm business,

- Keep the land in agriculture long-term, and

- Steward the land so it will remain productive in the future. 
While the similarities between viability and sustainability are not central to this paper, future thought should be directed toward understanding this shift and critically reflecting on the theoretical and applied implications, if any.

What follows is a literature review in which we explore the origins of the concept of agricultural viability and efforts to measure it. We then briefly review the literature on multi-organization collaborative efforts to define key food systems concepts and activities. We then describe the geographic context and the particular process that occurred in $\mathrm{SJC}$, discussing the implications of a collaborative effort to conceptualize and measure agricultural viability. Here it is important to note that multistakeholder food system initiatives are often messy and do not follow a linear temporal path. We have done our best to organize the process section in a logical fashion and we have also provided a visual timeline to help navigate. We conclude with the opportunities and challenges of using the Toolkit to frame these types of efforts.

\section{Literature Review}

Agricultural viability is a key term in conversations across the globe about the survival of farms. It is often used in relation to individual producers, groups of producers, and assessments of programmatic success. Viability often connotes ideals of "success" and sustainability," yet in the academic literature and policy setting, viability is often narrowly focused on farm productivity and economic returns (Adelaja, Sullivan, \& Lake, 2005; Barnes, Hansson, Manevska-Tasevska, Shrestha, \& Thomson, 2015; Bauman, Thilmany, \& Jablonski, 2017; Cocciarelli, Smalley, \& Hamm, 2011; D uane, 2010; Robertson et al., 2008). As such, authors tend to fail to adequately justify, or explain the justification for, selecting their definition. Few if any discuss the relevancy of their selected definition and metrics to the communities of concern. D espite this narrow focus, a standard measure of farm viability is still lacking (Savickiene, Miceikiene, \& Jurgelaitiene, 2015). Ireland, however, has been collecting data on the economic situation of Irish farms since 1996, using the Frawley and Commins' (1996) metric of farm viability, which is assessed as the ability of a farm business to remunerate family labor at the minimum agricultural wage and provide a $5 \%$ return on the capital invested in nonland assets. But this approach has not been widely adopted.

Measuring viability in terms of income, Smale, Saupe, and Salant (1986) and Salant, Smale, and Saupe (1986) studied viability of farms in Wisconsin, Mississippi, and Tennessee. They created a metric based on the ratio of farm and off-farm household income to consumption expenses, capital replacement costs, and principal payments. The authors theorized that farm households with a ratio of at least 1.0 can maintain their current business, while those with less than 1.0 cannot meet their financial obligations. The farm may survive in the short term by utilizing credit or savings, but the farm is not expected to be viable in the long run. While their methodology is relatively comprehensive because it reflects the surge in diversified onfarm activities and other income streams, the study encountered difficulty due to the absence of data on calculations of interest and debt ratios (O ’D onoghue, 2017). Brown, G oetz, and Fleming (2012) tested whether farm income diversification impacts farm viability, which they define as the change in the number of farms at the county level. In their analysis, the authors found that the impacts of farm income diversification are not always positive. Measuring agriculture viability is further complicated by yearly variations and external forces, including environmental and biological ones (e.g., droughts, floods, pest pressures, etc.).

D espite being the most discussed component of viability in the literature, Scott (2003) found differing opinions of what economic viability looked like. In her study of farm viability in Nova Scotia, Canada, Scott (2003) interviewed over 100 people tied to agriculture about their definition of viability. Their responses fell into four categories. The first category was economic viability and included income, debt, economic efficiency, farm income support programs, and fair farm pricing. The issue of fair price generated the most discussion and was the most universally agreed upon. As for the other three categories, interviewees noted the importance of ecological viability, the ability of the land and animals to sustain a productive farming operation; of human capital, the ability of the 
farmer, their family and employees to continue farming; and finally the importance of social capital, the ability of farmers and their community to work and live together. Further, the way in which the term "agricultural viability" is framed influences how interest groups measure viability and use the findings to contest wider politics of agriculture in a region (Cousins \& Scoones, 2010).

The causes of the decline in family farmers have been discussed at great lengths in the literature (Goldschmidt, 1947; O berholtzer, Clancy, \& Esseks, 2010). In fact, advocacy groups have been seeking to address the many challenges facing agriculture in the United States for over a half century, but over the last decade there has been a groundswell of interest in food and agriculture. Coupled with this general interest is growing concern regarding the continued survival of agriculture in the United States. Between 1992 and 2012, the U.S. lost nearly 31 million acres (12.5 million hectares) of land (Sorensen, Freedgood, D empsey, \& Theobald, 2018). Farmlands closest to urban centers face the greatest threat of development, despite providing important ecosystem and cultural services to urban residents (Brinkley, 2018). While SJC may be separate from the major urban centers of Vancouver and Seattle by bodies of water, the county is still impacted by urban growth because of its popularity as a vacation and second-home destination for urban residents. Population growth and mobility have led to intense demand for agricultural lands on the urban edge. In addition to the physical pressures, these urbanadjacent farmlands face additional challenges, including conflicts with non-farm neighbors over odor and noise; vandalism; local planning zoning laws that curtail agriculture and agriculture-related activities; and limited access to agriculture-related suppliers, capital, and services (Inwood \& Sharp, 2012). Lapping and FitzSimons (1982) argue that any policy or programmatic efforts to retain or preserve farmland must focus on improving the economic viability of agriculture. To this end, urban-adjacent farmlands often have the greatest economic potential because of their location on some of the nation's most productive soils (American Farmland Trust, n.d.). Additionally, their proximity to markets (Brown \& Miller, 2008;
Low \& Vogel, 2011) allows them to specialize in specialty crops, which often demand higher prices than commodity crops. Increasingly a wider array of nonprofit organizations, planning agencies, and government agencies in North America are developing and implementing policies and programs with the goal of improving the viability of agriculture (Clark, Inwood, \& Jackson-Smith, 2016). These programs are often in addition to already existing resources provided by traditional agricultural groups in the U.S. such as the Farm Bureau, the USD A, and the land-grant university system with its network of Cooperative Extension agents to support farmers. Some nontraditional programs emerged in response to a general critique of the role of the more traditional organizations in increasing the intensification, concentration, capitalization, corporatization, and globalization of agriculture (Marshall, 2000).

These nontraditional viability programs and policies go beyond those established to preserve and protect farmland, like conservation easements, use-value property taxation of farmland, lowdensity agricultural zoning, urban growth boundaries, right-to-farm laws, agricultural districts, and a governor's executive order to direct state infrastructure projects away from farmland. At its core, agriculture viability programs assert that changes at the farm level can lead to enhanced farm profitability and, as a result, to the preservation of farmlands. Farm viability programs often provide technical assistance - and in some cases, grants or access to land - to improve the profitability of farms. Farm viability programs have been implemented in Connecticut, Maine, Maryland, Massachusetts, Minnesota, New Jersey, New Y ork, O hio, Rhode Island, Pennsylvania, and Vermont

(Farmland Information Center, n.d.).

As more organizations become involved in the discussions around the viability of agriculture, it is important to consider how these different types of organizations can work together. Fortunately, there are numerous academic articles describing the process of multiple organizations or researchers coming together around a shared understanding of regional food systems (Aiking \& de Boer, 2004; Eriksen, 2013; Jablonski et al., in press; Kloppenberg et al., 2000; Koliba et al., 2017). These studies 
have shown numerous benefits that result from coordinating multi-organization efforts, including improved collaboration, enhanced resource investments, and critical alignment to reduce organizational inefficiencies (Jablonski et al., forthcoming). Yet a general trend across these different examples is the uniqueness of the processes implemented in each community. Hayati, Ranjbar, and Karami (2010) suggest that this type of multi-organizational effort requires a process and identification of metrics that need to be specific to the location and constructed within the socioeconomic context and ecological situation. While the community-level customization has many benefits, some communities may be overwhelmed at the prospect of developing their own unique process.

Given the nascent nature of many of these multi-organizational collaborative efforts and the uniqueness of the processes implemented in each community, there continue to be relatively few efforts guided by a standardized approach. As a result, the USD A convened a team of regional economic and food system specialists to develop the Toolkit, with the goal of guiding and enhancing the capacity of local organizations to make more deliberate and credible measurements of local and regional economic activity and ancillary benefits (Thilmany McFadden et al., 2016). Other authors have shown how the Toolkit can be used to conduct an economic impact assessment (Becot et al., 2018; Christensen, Jablonski, Stephens, \& Joshi, in press; Conner, Becot, \& Imrie, 2017). Instead of focusing on the implementation of a full economic impact assessment, this is the first paper to focus on how the first four modules of the Toolkit can be used to facilitate multi-organization collaboration during the earlier stages of food system discussion.

In the following sections we will discuss how the members of the VSP Work Group, a multiorganization collaboration, worked together to identify a shared definition of agriculture viability and metrics using the USD A Toolkit to facilitate the process.

\section{The Context and Process}

A ferry-served archipelago in the far northwest corner of the state, SJC is 174 square miles (451 square $\mathrm{km}$ ) and is the smallest county in Washington by land area and fourth smallest by total area (U.S. Census Bureau, 2010). While the county is centrally located between Seattle, Washington, and Vancouver, Canada, it is the only county in the state without a state highway (Figure 1). SJC holds a unique, island-based tradition of small-scale farming that originated in the homestead culture of the late 1800s.

To maintain and support the agricultural heritage of the county, the SJC county commissioners created the Agricultural Resource Committee of San Juan County (ARC) in 2005 (Figure 2). The mission of the ARC is to protect and restore agricultural resources in SJC (San Juan County, 2005). The ARC is composed of farmers and representatives from many organizations working to support agriculture in SJC. The ARC seeks to achieve its mission by advising SJC Council on relevant agricultural issues; identifying emerging opportunities; informing and educating elected officials and local citizens about the importance of agriculture; promoting programs, initiatives, and policies that strengthen and expand the agricultural economy; and effectively advocating on behalf of local farmers.

In 2011, the steering committee for SJC Agricultural Strategic Action Plan with representation from the Agricultural Resources Committee (ARC) of SJC, the SJC Land Bank, the San Juan Preservation Trust, Washington State University Extension, and Mulno Cove Creations, prepared an agricultural strategic action plan for the county. The plan identified key goals and strategies to prioritize the preservation of farmland and to generally strengthen agriculture in SJC. The report concluded, "As a result of this strategic planning process, it is clear that success in protecting farmland will ultimately be defined not only by the amount of farmland conserved, but also by the productive, profitable, and sustainable use of that farmland by local farmers, thereby contributing to a strong, diversified economy that benefits farmers and their community, while also building a viable and resilient local food system" (Bill, Clark, Hover, Jagel, \& Pratt, 2011, p. 10).

Building off a number of key priorities identified in the agricultural strategic action plan and a 
Figure 1. San Juan County, Washington, Cropland Data Layer, 2016.

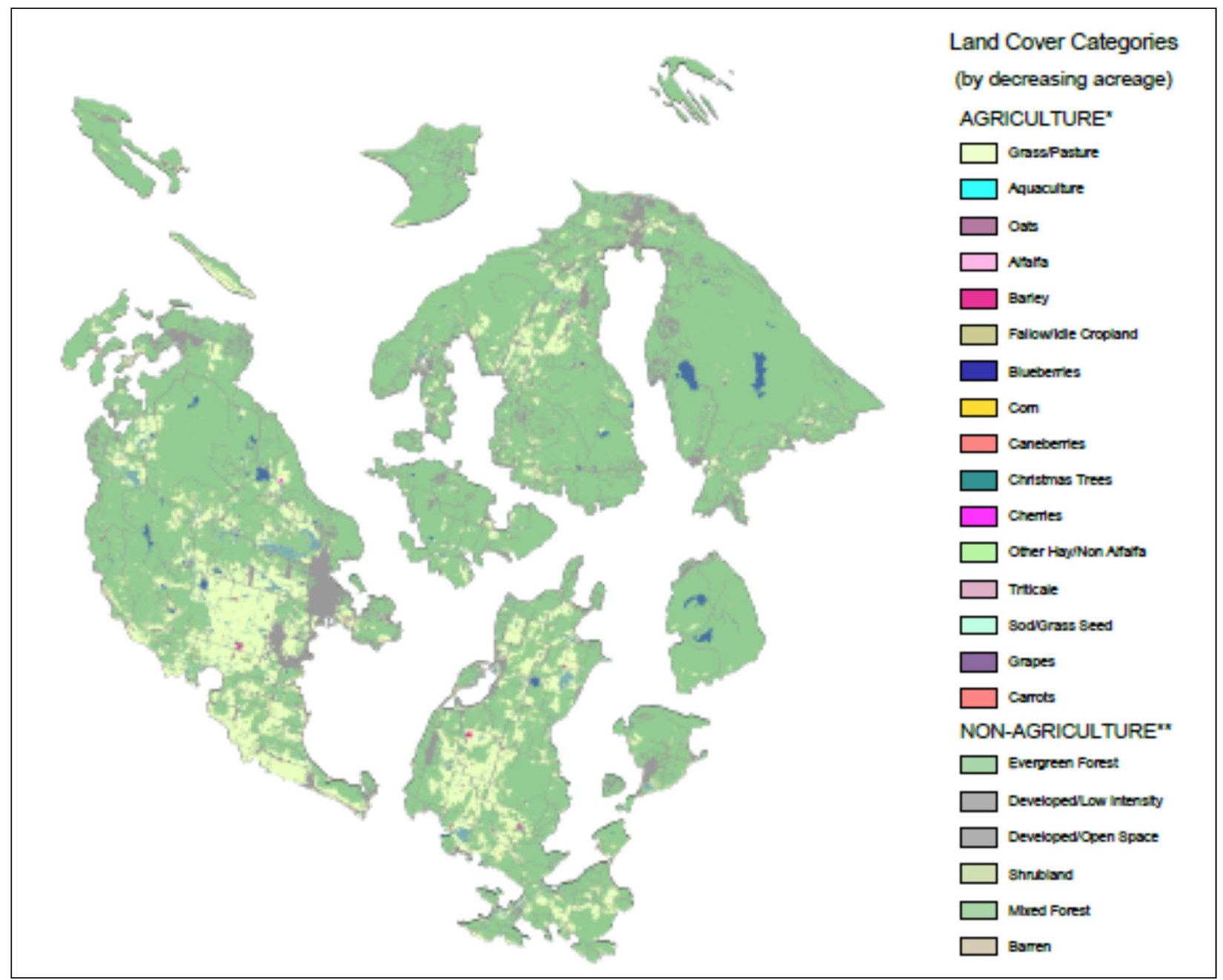

Source: USDA NASS (2016).

community needs assessment by the Community Foundation of the San Juan Islands (2015), the San Juan Islands Agricultural Guild, applied for and was awarded a USD A Local Food Promotion Program (LFPP) grant in 2015. Working in collaboration with the ARC, the Orcas Food Co-op, Northwest Agriculture Business Center, and Washington State University (WSU) Extension, the San Juan Islands Agricultural G uild intended to use the grant to assess the feasibility of establishing a food hub to coordinate the sales and distribution of food produced in San Juan County. The goals of the project were to increase food security, diversify and strengthen the local food economy, and promote access to healthy and sustainably produced foods.
As part of the feasibility study, the project team surveyed 80 San Juan County stakeholders, including 37 farmers, 28 food purveyors, five food manufacturers, four local distributors, four nonprofit organizations, and two public institutions. The purpose of the survey was to assess interest and willingness to utilize a food hub; it included questions about sales and market channels. In all, the survey results clearly showed SJC farmers' need for support in accessing new markets. As a result of the study, in addition to other work in the community, stakeholders wanted to conduct an assessment of the economic impact of agriculture in the county. They believed that understanding and effectively communicating the economic impact of 
Figure 2. San Juan Count Voluntary Stewardship Program Timeline at the State and County Level

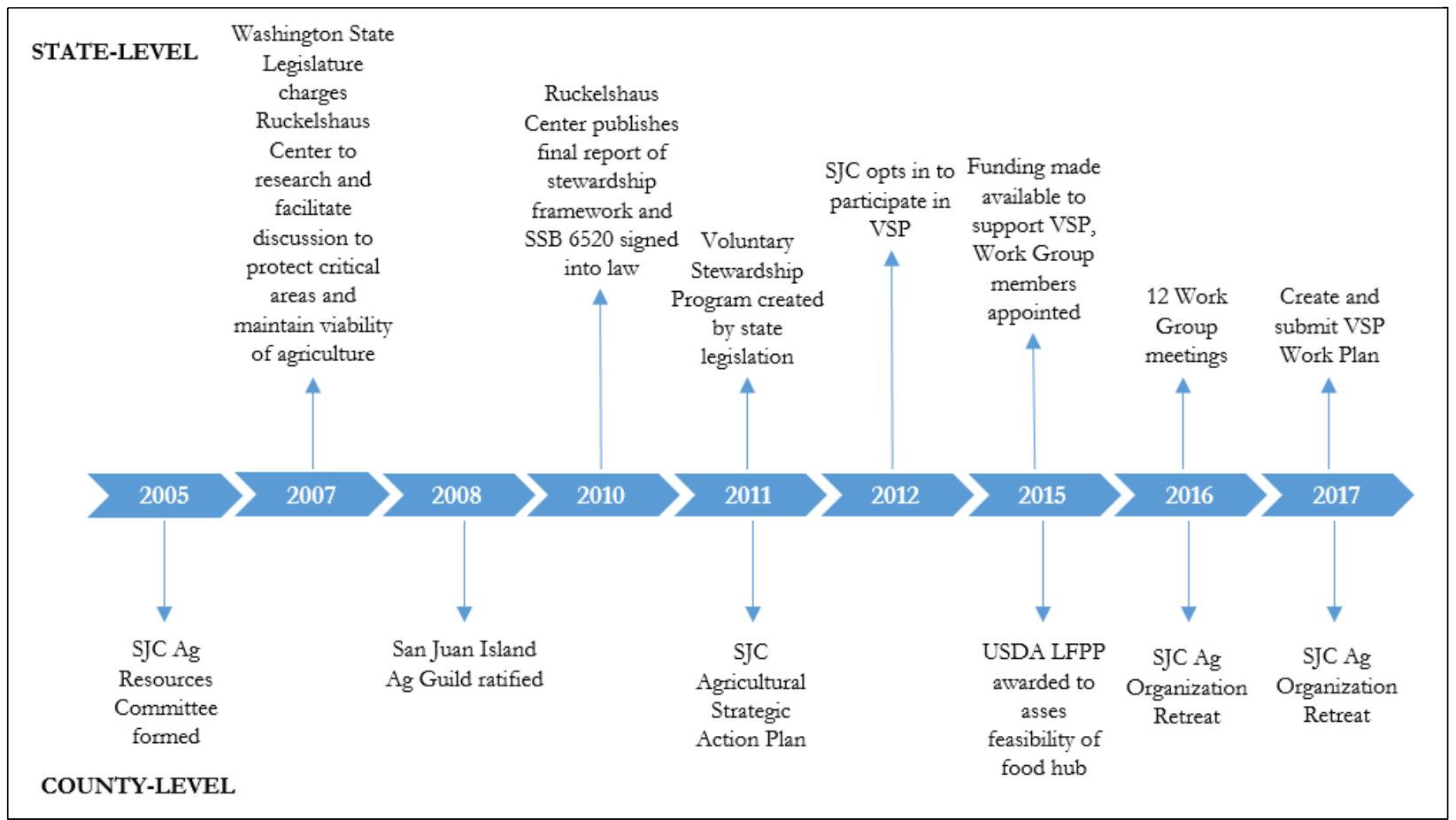

Abbreviations: SJ C: San Juan County; VSP=Voluntary Stewardship Program; USDA LFPP=U.S. Department of Agriculture Local Food Promotion Program

local agriculture could play an important role in securing additional support for agriculture and affecting future policy decisions in the county.

In early 2016, the ARC convened an Agricultural Organizations Retreat with participation from 16 organizations in SJC. Goals of the retreat included identifying short- and long-term priority issues and projects, aligning efforts and resources to reduce redundancies, and increasing collaboration and resource-sharing to work toward common goals. Participating organizations were asked to fill out a questionnaire prior to the retreat to describe their mission as it relates to agriculture (Table 1).

While work continued at the county level, there were efforts at the state level to address tensions between agricultural and environmental groups. In 2007, the Washington State Legislature charged the Ruckelshaus Center - a joint effort of Washington State University and the University of Washington established to foster collaborative public policy in the state of Washington and the Pacific Northwest- to examine the tension between maintaining viable agriculture and protecting
Critical Aquifer Recharge Areas (CARA), as defined by the state's G rowth Management Act (G MA), which includes wetlands, fish and wildlife habitat conservation areas, geologically hazardous areas, critical aquifer recharged areas, and frequently flooded areas (San Juan County VSP, 2018). The G MA was passed in 1990 and 1991, and requires all counties to establish ordinances to protect critical areas. After the GMA became law, several counties exempted agriculture from their critical area ordinances, but legal challenges from environmental groups in the early 2000s ended the exemption.

The result of the Ruckelshaus Center report was the Voluntary Stewardship Program (VSP), enacted by the state legislature in 2011. The goal of the VSP is to provide an alternative approach for counties to address growth management requirements for agricultural activities. The program uses a watershed-based, collaborative stewardship planning process, relying on incentive-based practices that protect critical areas, promote viable agriculture, and encourage cooperation among diverse 
Table 1. Participants in the 2016 SJ C Agricultural Organizations Annual Retreat

\begin{tabular}{|c|c|}
\hline Organization Name & Mission as it relates to agriculture \\
\hline San Juan Island Food Co-op & $\begin{array}{l}\text { To provide access to local and regional food and goods that are organic, } \\
\text { sustainable and fairly produced with the smallest carbon footprint. The Co-op } \\
\text { encourages conscientious consumption and nurtures community connections. }\end{array}$ \\
\hline San Juan Island Transport Service & To link farmers and producers to markets with transport of goods. \\
\hline San J uan Islands Agricultural Guild & $\begin{array}{l}\text { To foster a vibrant, resilient and sustainable local agriculture and food system in } \\
\text { San Juan County. }\end{array}$ \\
\hline Northwest Agriculture Business Center & To support the economic sustainability of farms in Northwest Washington. \\
\hline Orcasong Farm & $\begin{array}{l}\text { To promote regenerative land stewardship, holistic community development, envi- } \\
\text { ronmental advocacy, \& ecological awareness through education, demonstration, } \\
\text { mindful leadership development, and the incubation of ecologically responsible } \\
\text { commercial enterprises. }\end{array}$ \\
\hline
\end{tabular}

SJC Food Hub To coordinate sales and distribution of local food in SJC.

To amplify the efforts of Thriving Communities initiatives (food, shelter, economy,

Thrive San J uan Islands/Thriving Salish Sea healthcare, water, etc.) for greater engagement and learning from/about/ with one another. Leadership and organizational resources, potential for collaborative funding and community-of-practice development are beneficial to serving the whole system.

SJC Agricultural Resources Committee To restore and protect agriculture in SJC.

To work with land managers to develop and implement sustainable land-use San J uan Islands Conservation District practices that protect and conserve SJC's soil, water, and natural resources for farming, forestry, and wildlife.

To support a sustainable food $\&$ farms community through promoting events and

San Juan Islands Visitors Bureau businesses to travelers who love the San Juan Islands and are looking for local culinary travel experiences that support local farmers, restaurants and artisan food producers.

Washington State University Extension To provide practical research-based information to the public.

SJC Land Bank To preserve agricultural land in SJC.

Farmers Collaborative

To increase communication between all Island farmers, create a network of support and information sharing, and create a more singular voice to advocate for our needs.

The Orcas Food Co-op exists so that owners, customers, food producers and the Orcas Island Community will have: 1. Equitable and affordable access to high quality, local and organic foods that support diverse nutritional needs. 2. A sus-

Orcas Food Cooperative tainable local food system with strong regional connections. As a cooperative, we also operate according to the cooperative principles, which include cooperation among cooperatives and working for the sustainable development of our community.

To strengthen and diversify the economy of SJC. We believe a strong economy builds a strong community. The EDC works to build an environment that helps

SJ C Economic Development Council business owners create jobs. We serve business: linking organizations and resources, providing valuable information, rendering assistance and advocating for an improved island business environment.

To provide permanently affordable access to land for such purposes as quality housing, sustainable agriculture and forestry, cottage industries and co-

Lopez Community Land Trust operatives by forever removing the land from the speculative market. Develop and exercise responsible and ecological practices, which preserve, protect and enhance the land's natural attributes. Serve as a model in land stewardship and community development by providing information, resources and expertise.

Note: The groups in bold participated in the ARC Agricultural Organization Retreat in early 2016. 
stakeholders. In 2012, SJC became one of 28 counties in Washington State that opted to participate in the VSP. Since all of SJC is designated as a CARA, the VSP applies to all agricultural activities in the county. For this reason, baseline data becomes not only essential for the development of sound VSP benchmarks and goals, but also valuable for current and future assessment of other ongoing and emerging agricultural and local food initiatives in the county. Funding to implement the program did not become available until 2015.

The intent of the VSP statute is to protect and enhance critical areas where agricultural activities take place while maintaining and improving the long-term viability of agriculture. Y et early documents from the Ruckelshaus Center fail to define what is meant by agricultural viability (The William D. Ruckelshaus Center, 2007; 2008; 2010). It was not until September 2016 that the Washington State Conservation Commission suggested its first definition of agricultural viability (Washington State Conservation Commission, 2016a). This first definition was quite narrow and simply defined viability as a farm's ability to meet its financial obligations. By November 2016, this definition for agricultural viability was vastly expanded to include the spatial, economic, temporal, and environmental components presented in the literature review (Washington State Conservation Commission, 2016b). The expanded definition was adopted by the Washington State Department of Agriculture, the Washington State Conservation Commission, and Washington State Farm Bureau. These same agencies stressed that the definition was meant to be a starting point and that the statute did not include specific language defining viability. Countyspecific work groups would be expected to agree upon their own definition and would be responsible for demonstrating how they would maintain and enhance agricultural viability, as they defined it, 10 years after adoption of the statute.

As funding to support the VSP became available, the county established the Watershed Work Group in D ecember 2015 to develop an action plan. The work group included representation from seven organizations that also participated in the ARC Agricultural O rganization Retreat (whose names are in boldface in Table 1). The retreat provided a valuable foundation for collaborative efforts moving forward. In addition to the seven organizations that attended the retreat, the SJC Council appointed representatives from 11 farms, one resource management organization, three county departments, one environmental organization, and three tribes to the work group (San Juan County VSP, 2018).

The work group was charged with developing a ten-year work plan specifying the purpose, goals, and measurable objectives for enhancing agricultural viability while protecting critical areas in SJC. Between January 2016 and 0 ctober 2017, the group met 12 times as a whole. In addition, two subcommittees were established to discuss and work out the details of the critical areas and agricultural viability components of the plan. The work plan focused on establishing a baseline and monitoring approach to conserve critical landscapes and to maintain and improve the long-term viability of agriculture. Under the VSP, agricultural producers can voluntarily develop an individual stewardship plan. There is no penalty for producers who choose not to participate. The VSP is incentivebased and does not restrict new or existing agricultural activities. The San Juan Islands Conservation District (SJICD) was designated as the technical assistance provider to the VSP and is responsible for the VSP monitoring and reporting at the watershed scale.

In 2016, one of the work group participants and the co-author of this paper reached out to one of the team members that helped to develop the USD A Toolkit. The co-author was seeking assistance in guiding and enhancing the capacity of the work group to make more deliberate and credible measurements of viable agriculture in SJC. Together they organized a training for the VSP Work Group Agricultural Viability Subcommittee (Subcommittee) on March 10, 2017, in Friday Harbor, Washington. There were 15 attendees. The training reviewed the first four modules of the Toolkit: (1) framing your community economic assessment process, (2) using secondary data sources, (3) generating and using primary data, and (4) engaging your community process with data. 


\section{Framing the Community Assessment Process: Defining the Parameters}

As a first step, in line with the first module in the USD A Toolkit, the SJICD proposed a logic model to help frame the community process and define the parameters of the VSP. The logic model included two strategic goals of the VSP (maintain and improve the viability of agriculture, and protect and enhance critical areas) and highlighted the relationship between them. The logic model included potential objectives, benchmarks, and metrics (Figure 3).

The SJICD sent the draft model out to the work group and solicited feedback. Some of the feedback was incorporated into the model, which was captured in red. The logic model was a starting point from which in-depth conversations continued to occur. Work group members struggled with three major challenges between 2016 and 2017:
(1) assembling the right team, (2) defining agricultural viability, and (3) delineating the boundaries of the project. The results of this process are presented in the SJC VSP Work Plan (SJC VSP, 2018).

The first challenge confronted by the work group was making sure the right people were around the table. As one working group member noted, "The Conservation District is the logical primary technical assistance provider for VSP goal number two [Protect and Enhance Critical Areas in Areas with Ag Activities]. VSP goal number one [Maintain and Improve Long-term Viability of Agriculture], however, extends beyond resource protection and includes objectives related to agricultural production, infrastructure, and economics. It would be logical to involve agencies that specialize in research and providing technical assistance on such topics, for example, WSU Extension, the SJC Economic Development Council, and the SJC

Figure 3. April 2016 Voluntary Stewardship Program Agricultural Viability Goal and Benchmarks Logic Model

\begin{tabular}{|c|c|c|c|c|}
\hline \multirow{2}{*}{ Strategic Goals } & \multirow{2}{*}{$\begin{array}{c}\text { Objectives to Achieve } \\
\text { Goals }\end{array}$} & \multicolumn{3}{|c|}{ Benchmarks and Metrics } \\
\hline & & What to Measure & How / who & 2016 Baseline Data \\
\hline $\begin{array}{l}\text { Maintain and } \\
\text { Improve Long-term } \\
\text { Viability of } \\
\text { Agriculture }\end{array}$ & $\begin{array}{l}\text { Maintain/increase Ag production } \\
\text { Maintain or increase designated } \\
\text { Ag land } \\
\text { Maintain/increase participation } \\
\text { and implementation of } \\
\text { conservation practices to } \\
\text { enhance Ag activities } \\
\text { - Maintain and improve a vibrant } \\
\text { Ag economy } \\
\text { - Assess adequate Ag } \\
\text { infrastructure (Define } \\
\text { infrastructure, inventory, and ID } \\
\text { gaps) } \\
\text { - Provide technical assistance and } \\
\text { information }\end{array}$ & $\begin{array}{l}\text { - Available financial } \\
\text { incentives } \\
\text { \# of Ag operators } \\
\text { \# of Resource Management } \\
\text { Conservation Plans (Farm } \\
\text { Plans) } \\
\text { - Acres of land in Ag } \\
\text { production }\end{array}$ & $\begin{array}{l}\text { - Parcel Level-Technical } \\
\text { assistance: acreage in } \\
\text { Ag production, \# of } \\
\text { people provided } \\
\text { assistance for VSP } \\
\text { - Watershed level- } \\
\text { Conservation District; } \\
\text { \# of Farm Plans } \\
\text { participating; } \\
\text { Reporting } \\
\text { requirements } \\
\text { - Promote Ag. Economy } \\
\text { - ARC, WSU. Ag Guild } \\
\text { Education - partners }\end{array}$ & $\begin{array}{l}\text { - Estimated acreage of Ag } \\
\text { activities: xx acres } \\
\text { Growing Our Future } 2011 \\
\text { USDA census (2012): } \\
\text { - } \text { \# of farms: } 274 \\
\text { 15,669 a. } \\
\text { - Market Value of } \\
\text { Ag Products: } \\
\text { 4,245,000 } \\
\text { - Average size of } \\
\text { farm: } 57 \text { acres } \\
\text { - Median size of } \\
\text { farm: } 26 \text { acres }\end{array}$ \\
\hline $\begin{array}{l}\text { Protect and Enhance } \\
\text { Critical Areas in } \\
\text { Areas with Ag } \\
\text { Activities }\end{array}$ & $\begin{array}{l}\text { Maintain/increase participation } \\
\text { and implementation of } \\
\text { conservation practices to protect } \\
\text { and enhance critical areas } \\
\text { - Fish and Wildife Habitat areas: } \\
\text { maintain or increase acreage of } \\
\text { protected habitat } \\
\text { - Wetlands: protect and enhance } \\
\text { current functions } \\
\text { - Critical Aquifer Recharge areas: } \\
\text { implement irrigation efficiencies, } \\
\text { promote water conservation and } \\
\text { water quality enhancement } \\
\text { activities } \\
\text { - Reduce geologic hazards } \\
\text { Protect and enhance floodplain } \\
\text { area and function. }\end{array}$ & $\begin{array}{l}\text { Acres/stream miles of } \\
\text { wetlands, riparian areas \& } \\
\text { fencing } \\
\text { - Acres of fish \& wildlife } \\
\text { habitat protected or } \\
\text { enhanced } \\
\text { - Habitat/WQ ratings (NRCS } \\
\text { tools) } \\
\text { - Number of projects using } \\
\text { water quality or quantity } \\
\text { conservation BMPs (\# of } \\
\text { Catchments installed? Acre- } \\
\text { feet of water stored } \\
\text { annually?) } \\
\text { - Participation: number of } \\
\text { Farm Plans \& types of } \\
\text { conservation practices } \\
\text { implemented (\# of BMPs } \\
\end{array}$ & $\begin{array}{l}\text { Parcel level } \\
\text { Technical assistance:\# } \\
\text { of Farm Plans and } \\
\text { types of conservation } \\
\text { practices } \\
\text { implemented, acreage } \\
\text { affected } \\
\text { - Watershed level } \\
\text { Conservation District: } \\
\text { acreage \& \#'s overall } \\
\text { - Soil Health/Structure } \\
\text { - Water Catchments (\# } \\
\text { of) } \\
\text { Climate change/ } \\
\text { Adaptive Mgmt }\end{array}$ & $\begin{array}{l}\text { - Estimated acreage of } \\
\text { critical areas } \\
\text { intersecting with Ag: } \\
\text { - Geologic Hazard Areas: } \\
\text { (xx acres) } \\
\text { - Streams, Lakes and } \\
\text { ponds (xx lineal feet?) } \\
\text { - Wetlands: (xxx acres) } \\
\text { - Frequently Flooded } \\
\text { Areas (xx acres) } \\
\text { - Salmon - streams and } \\
\text { nearshore (FWHCA) } \\
\text { - Aquifer Recharge } \\
\text { mapping } \\
\text { - Other FWHCAs - in } \\
\text { process }\end{array}$ \\
\hline
\end{tabular}

Source: San Juan Islands Conservation District, 2016a. 
Agricultural Resources Committee. I also believe that the VSP could become a more collaborative, holistic effort involving teams of specialists and mentors who work with farmers collaboratively" (Comment 43 from SJICD , 2016b). This quotation summarizes the need to assemble a solid leadership team for the study that incorporates a broad range of skill sets, expertise, and perspectives (Thilmany McFadden, 2016). All the organizations noted in the quotation were eventually asked to take part in the VSP process to some degree.

The second challenge was coming up with a shared understanding of agricultural viability. As one member of the work group put it, "Interestingly, there are some stark differences in how some of us on the Subcommittee interpret what exactly it is that we are supposed to be doing with VSP and Ag Viability." This member then went on to explain the role of the Toolkit in bringing the group together around a shared understanding of agricultural viability. The Toolkit includes questions to help team members clarify definitions and data needs for establishing the relationship between the project objectives and economic and non-economic objectives. O ne of the central challenges the work group faced was whether to focus exclusively on the more quantifiable economic metrics of viability or to also include the often intangible social viability of agriculture, like those noted by Scott (2003) in Nova Scotia. The work group concluded that agricultural viability includes:

- Economic Prosperity: Support a thriving and viable local farm economy that increases profitability of local farmers.

- Farm Retention and Expansion: Maintain and increase the number of acres and/ or farms in long-term commercial agricultural production by making farmland available and increasing the capacity of farmers.

- Farm Stewardship and Sustainability: Maintain and increase healthy agricultural natural resource systems that are adaptable to climate change.

- Supportive Regulatory Environment: Establish a supportive regulatory environment.

- Agricultural Ethic: Increase the social value of a local food system (San Juan County Voluntary Stewardship Program, 2018).

The work group recognized that many factors that contribute to agricultural viability are beyond local control, particularly climate and global events. As a result, progress toward the agricultural viability goals will be monitored every two years through a survey of producers. Unlike performance metrics associated with critical areas of protection, measures for agricultural viability are not tied to measurable benchmarks. Progress toward attaining agricultural viability goals and strategies will not be used to determine success or failure of VSP but rather to inform future adaptive management strategies.

The third challenge was drawing boundaries around the scope of the study. The work group had a clear geographic boundary, SJC, which helped with secondary data collection, but struggled with the "level of analysis" (Thilmany McFadden, 2016). Some work group participants wanted to include operations that do not sell their products, such as personal or hobby farms, while others wanted to only include producers engaged in market transactions. The work group decided that its assessment of agricultural viability needed to encompass all forms of agriculture, including family and community food systems that are not part of the marketplace.

The Toolkit was a crucial resource for the work group in the early planning stages of the process. The Toolkit would also prove useful in the data-collection process. After making these decisions, the next step in the VSP process was collecting data to assess progress toward agricultural viability goals.

\section{Using Secondary and Primary Data Sources}

The Toolkit provides resources to help community groups identify and access available secondary data sets, evaluate key strengths and drawbacks of datasets, decide when primary data is necessary, and what to do once the decision is made to collect primary data. D uring the 2017 Toolkit Training, much of the discussion focused on the pros and cons of primary versus secondary data collection. The training facilitators, D r. Becca Jablonski from 
Colorado State University and Samantha Schaffstall from the USD A, noted that community groups often jump to surveying producers. They suggested using available secondary data first and then developing primary data collection tools to most effectively fill those gaps. The workshop facilitators recognized that federal government data is not readily available and many community members performing assessments do not feel comfortable or do not know the best way to use the data to tell their story. After reviewing existing secondary data sources during the Toolkit training, including the USD A's Agricultural Census, the Local Food Survey, the D ollar Bill series, Food Consumption Intakes, and Consumer Food Expenditure, some participants still had concerns about the accuracy of the data. The training facilitators reviewed the methodology and sampling approach of the secondary datasets and encouraged participants to review the resources. In the final work plan, the work group used USD A Census data to help establish a baseline against which to measure agricultural viability.

Using secondary data from the 2007 and 2012 Agricultural Censuses, the SJC VSP Work Plan Report (San Juan County Voluntary Stewardship Program, 2018) describes general trends in SJC agriculture, finding,

The market value of farm products has increased 17\% since 2007. Reflecting a national trend, crop production has surpassed livestock production for the first time in the history of the USD A census data. The 2012 census also indicates that since 2007 , there has been a $6 \%$ decrease in the number of farms, a $27 \%$ decrease in acres that are actively farmed, and a $23 \%$ decrease in the average size of farms. Farmers in San Juan County are making more money on less acreage. (p. 49)

In addition to the secondary data, the work group felt they needed the primary data provided by a survey.

As noted in the previous section, the VSP Work Group broke down agricultural viability into five subgoals: (1) economic prosperity, (2) farm retention and expansion, (3) farm stewardship and sustainability, (4) supportive regulatory environment, and (5) agricultural ethic. VSP Work Group members, SJICD staff, and the SJC ARC, in consultation with WSU Social and Economic Science Research Center and D r. Mike Brady, WSU economist and survey specialist, created a survey using the subgoals. The survey was sent to established farms. Respondents were able to complete either a paper survey or web-based survey. The SJICD received 71 completed or partially completed responses from a list of 249 producers, for a response rate of $29 \%$. The survey had 24 questions and collected information about number of acres leased or owned, market channels, lost sales, challenges to farming, future plans for farming, barriers to expansion, gross sales, net profit, and owner equity (ratio of debt to assets).

According to the survey results, the ability of local producers to find affordable, skilled labor is one of the greatest challenges farmers face in San Juan County. The survey found that the average age of respondents was 63 years old, which reflects an aging population of farmers and raises a potential concern for farm transitions. Farmers reported the total number of acres that they farmed in 2014, 2015 , and 2016, revealing a 10\% increase between 2014 and 2015. It should be noted that this is the total acreage from a subset of farmers in the county (71 respondents) and does not reflect total agricultural activity in San Juan County. Farming in San Juan County tends to be done on a relatively small scale. For example, the 2012 Census of Agriculture states that the median size of farms in San Juan County is 26 acres (11 ha), with an average size of 57 acres ( $23 \mathrm{ha}$ ). Statewide the median farm size is 24 acres (10 ha), with an average size of 396 acres (160 ha). The market value of agricultural products sold in San Juan County was US\$15,492 on average per farm, according to the 2012 Census of Agriculture, while statewide the average per farm was US\$244,859.

The SJICD will conduct the survey and collect data every two years, with guidance and input from the work group and stakeholders. Unlike the measures to assess the protection of critical areas, the measures for agricultural viability are not tied to measurable benchmarks. As a result, data collected 
through the survey regarding agricultural viability will not be used to determine the success or failure of the VSP, but rather to inform ongoing and future management activities. After survey implementation, the work group will determine if the agricultural viability goals are being met. If they are not, the work group will develop management processes with the intent to increase agricultural viability, and the findings will be shared with the broader agricultural community.

\section{Conclusion}

D efining and measuring farm viability is largely dependent on the goals of and resources available to the community, but the USD A Toolkit is a valuable resource that can help to coordinate these efforts. As one participant summed it up, "the VSP process was kind of crazy. When I feel lost along the way, I would check in with the Toolkit. It became sort of like a mentor." Instead of needing to create a whole new process from scratch, the Toolkit provided a roadmap. While SJC is unique geographically, many of the challenges the VSP Work Group confronted while creating the work plan are familiar to those working with multiple organizations to find common ground. Key to the success of this project and others like it is assuring that participants know that the project can have important implications for individual organizations and the entire community. It is also important to recognize the flexibility of the tool and that work group participants could be working on more than one module simultaneously.

Participants saw the VSP Work G roup as a unique opportunity to increase the visibility of their local work at the state level. Further, as Koliba et al. (2017) found, this type of multiorganization collaboration gives participants the opportunity to strengthen their networks, allowing for improved information-sharing and for strengthening partnerships with organizations from a broad spectrum of fields, from economic development to tribal advocacy. Work group participants also felt that findings from the process could be valuable to ongoing work within their own organizations and could result in enhanced resource investment. The Agricultural Guild, for example, plans to use the findings from the viability survey for future grant proposals and as an evaluation tool.

At the same time, however, the Toolkit is not without its challenges. Some work group members were hesitant to use the Toolkit because it was intimidating and dense. The economic language can be difficult to grasp, and many felt that despite the Toolkit authors' attempts to utilize laypeople terms throughout, the document still was not very accessible. It was not until the in-person training that many of the work group participants saw the potential of the Toolkit. During the training, people had an opportunity to engage with the Toolkit and to ask questions. Considering how to create opportunities for communities to use the Toolkit that are not as costly will be important for the successful utilization of the Toolkit. There were also suggestions for changes in language and structure that might make the Toolkit more accessible, such as a more flexible organization of the modules. This type of change would recognize that sometimes communities will be moving forward on multiple modules simultaneously, but it is unclear how a change such as this could be reflected in the resource. Moving forward with the project, it will be important for the VSP Work G roup to return to the Toolkit, recognizing the iterative nature of these types of projects.

Each of the organizations with representation on the work group share a common goal of creating a more robust food system. Supporting the economic viability of farms is central to that goal. Understanding how farmers are currently faring economically is a crucial step toward evaluating the impact of current efforts in the county and the development of future planning. The agricultural viability assessment study provides a benchmark and showed work group members the limitation of existing data and the difficulty of implementing a successful survey. The USD A AMS Toolkit played an integral role in supporting the VSP Work Group's efforts to create a meaningful definition for agricultural viability and to develop an assessment tool. 


\section{References}

Adelaja, A. O ., Sullivan, K., \& Lake, M. B. (2005, March). A gricultural viability at the urban fringe. Paper presented at International Conference on Emerging Issues Along Urban/ Rural Interfaces: Linking Science and Society, Atlanta, GA. Retrieved from http:/ / emergingissues.interfacesouth.org/ pastconferences/2005proceedings.pdf

Aiking, H., \& de Boer, J. (2004). Food sustainability: D iverging interpretations. British F ood Journal, 106(5), 359-365. https:/ / doi.org/ 10.1108/ 00070700410531589

American Farmland Trust. (n.d.). Fresh food grown on the urban fringe [G raph]. Retrieved from http:/ / 162.242.222.244/ programs/ localfood/ fresh-food-grown-on-the-urban-fringe.asp

Barnes, A. P., Hansson, H., Manevska-Tasevska, G., Shrestha, S. S., \& Thomson, S. G. (2015). The influence of diversification on long-term viability of the agricultural sector. L and U se Policy, 49, 404-412. https:/ / doi.org/ 10.1016/ j.landusepol.2015.08.023

Bauman, A., Thilmany, D ., \& Jablonski, B. B. R. (2017). Evaluating scale and technical efficiency among farms and ranches with a local market orientation. Renewable A griculture and F ood Systems, 1-9. https:/ / doi.org/ 10.1017/ S1742170517000680

Becot, F. A., Sitaker, M., Kolodinsky, J. M., Morgan, E. H., Wang, W., Gamer, J., ... Seguin, R. A. (2018). Can a shift in the purchase of local foods by Supplemental Nutrition Assistance Program (SNAP) recipients impact the local economy? Renewable A griaulture and F ood Systems, 1-12. https:/ / doi.org/ 10.1017/ S1742170518000327

Bill, P., Clark, T., Hover, K., Jagel, C., \& Pratt, B. C. (2011). G rowing our future: A n agriaultural strategic action plan for San Juan County, W A . Agricultural Resources Committee of San Juan County, San Juan Preservation Trust, \& San Juan County Land Bank. Retrieved from https:/ / www.sanjuanco.com/ documentcenter/ view/ 16442

Brinkley, C. (2018). High rugosity cities: The geographic, economic and regulatory pathology of America's most nonconcentric urban areas. L and U se Policy, 73, 215-224. https:/ / doi.org/ 10.1016/ j.landusepol.2018.01.024

Brown, J. P., G oetz, S. J., \& Fleming, D . A. (2012, August). M ultifunctional agriculture and farm viability in the U nited States. Presented at the Agricultural and Applied Economics Association Annual Meeting, Seattle, Washington. Retrieved from https:/ / ageconsearch.umn.edu/ bitstream/126929/2/ bgf_AAEA.pdf

Brown, C., \& Miller, S. (2008). The impacts of local markets: A review of research on farmers markets and Community Supported Agriculture (CSA). A merican Journal of A gricultural E conomics, 90(5), 1298-1302. https:// doi.org/ 10.1111/j.1467-8276.2008.01220.x

Christensen, L., Jablonski, B. B. R., Stephens, L., \& Joshi, A. (2018). Economic outcomes of farm to school: D eveloping an approach for primary and secondary financial data collection of producers selling to schools. Journal of A griculture, Food Systems, and Community D evelopment. Advance online publication. https:/ / doi.org/ 10.5304/ jafscd.2018.08C.002

Clark, J. K., Inwood, S. M., \& Jackson-Smith, D . (2016). Exurban farmers' perceptions of land use policy effectiveness: Implications for the next generation of policy development. Journal of A griaulture, Food Systems, and C ommunity D evelopment, 5(1), 39-55. http:/ / dx.doi.org/ 10.5304/ jafscd.2014.051.001

Cocciarelli, S., Smalley, S., \& Hamm, M. (2011). Farm viability and development work group: Michigan G ood Food Work Group Report No. 4 of 5. East Lansing, MI: C.S. Mott G roup for Sustainable Food Systems at Michigan State University. Retrieved from http:// www.michiganfood.org/ uploads/ files/ Farm_Viability_Report.pdf

Community Foundation of San Juan Island. (2015). C ommunity needs task force report. Retrieved from http:/ / sjicf.org/ news/ community-news/ 2015-community-needs-task-force-report/

Conner, D ., Becot, F., \& Imrie, D . (2017). Critical reflections on the USD A local food economics toolkit. Journal of A griculture, F ood Systems, and Community D evelopment, 7(2), 117-125. https:/ / doi.org/ 10.5304/ jafscd.2017.072.001

Cousins, B., \& Scoones, I. (2010). Contested paradigms of 'viability' in redistributive land reform: Perspectives from southern Africa. The Journal of Peasant Studies, 37(1), 31-66. https:/ / doi.org/ 10.1080/ 03066150903498739

Duane, T. P. (2010). Increasing the public benefits of agricultural conservation easements: An illustration with the Central Valley Farmland Trust in the San Joaquin Valley. Journal of E nvironmental Planning and Management, 53(7), 925945. https:/ / doi.org/ 10.1080/ 09640568.2010.495487

Eriksen, S. N. (2013). D efining local food: Constructing a new taxonomy - three domains of proximity. A da A griaulturae Scandinavica: Section B, Soil \& Plant Scienœ, 63(sup.1), 47-55. https:/ / doi.org/ 10.1080/ 09064710.2013.789123 
Journal of Agriculture, Food Systems, and Community Development

ISSN: 2152-0801 online

https:/ / www.foodsystemsjournal.org

Farmland Information Center. (n.d.). Enhance agricultural viability. Retrieved March 4, 2018, from http:/ / www.farmlandinfo.org/ policies-programs/ enhance-agricultural-viability

Frawley, J. P., \& Commins, P. (1996). The changing structure of Irish farming: Trends and prospects (Rural Economy Research Series No. 1). Dublin: Teagasc.

Goldschmidt, W. R. (1947). A s you sow: Three studies in the social consequences of agribusiness (Vol. 5). Lanham, MD: Rowman $\&$ Littlefield Publishers.

Hansen, J. W. (1996). Is agricultural sustainability a useful concept? A gricultural Systems, 50(2), 117-143. https:/ / doi.org/ 10.1016/ 0308-521X (95)00011-S

Hayati, D ., Ranjbar, Z., \& Karami, E. (2010). Measuring agricultural sustainability. In E. Lichtfouse (Ed.), Biodiversity, Biofuels, A groforestry and Conservation A griculture (pp. 73-100). Springer, D ordrecht. https:// doi.org/ 10.1007/ 978-90-481-9513-8_ 2

Hinrichs, C. (2010). Conceptualizing and creating sustainable food systems: How interdisciplinarity can help. In A. BlayPalmer (Ed.), Imagining sustainable food systems: Theory and practice (pp. 17-36). Farnham, Surrey: Ashgate. https:/ / doi.org/ 10.4324/ 9781315587905-2

Inwood, S. M., \& Sharp, J. S. (2012). Farm persistence and adaptation at the rural-urban interface: Succession and farm adjustment. Journal of Rural Studies, 28(1), 107-117. https:/ / doi.org/ 10.1016/ j.jrurstud.2011.07.005

Jablonski, B. B. R., Angelo, B., Fox, D., Christensen, L., \& Thilmany McFadden, D . (in press). Leveraging urban and statewide food planning to support improved regional food outcomes. Sustainability.

Kloppenburg, J., Jr., Lezberg, S., D e Master, K., Stevenson, G ., \& Hendrickson, J. (2000). Tasting food, tasting sustainability: D efining the attributes of an alternative food system with competent, ordinary people. $\mathrm{H}$ uman 0 rganization, 59(2), 177-186. https:/ / doi.org/ 10.17730/ humo.59.2.8681677127123543

Koliba, C., Wiltshire, S., Scheinert, S., Turner, D ., Zia, A., \& Campbell, E. (2017). The critical role of information sharing to the value proposition of a food systems network. Public M anagement Review, 19(3), 284-304. https:/ / doi.org/ 10.1080/ 14719037.2016.1209235

Lapping, M. B., \& FitzSimons, J. F. (1982). Beyond the land issue: Farm viability strategies. G eoJournal, 6(6), 519-524. https:/ / doi.org/ 10.1007/ BF00425315

Low, S., \& Vogel, S. (2011). D irect and intermediated mark eting of local foods in the U nited States (ERR-128). Washington, D .C.: U.S. D epartment of Agriculture, Economic Research Service. Retrieved from https:/ / www.ers.usda.gov/ webdocs/ publications/ 44924/ 8276 err128_2_.pdf?v=0

Marshall, A. (2000). Sustaining sustainable agriculture: The rise and fall of the Fund for Rural America. A griculture and H uman V alues, 17(3), 267. https:/ / doi.org/ 10.1023/ A:1007640300392

O’D onoghue, C. (2017). Farm household microsimulation modelling: Viability. In C. O'D onoghue (Ed.), Farm-level microsimulation modelling (pp. 321-362). Cham, Switzerland: Springer International Publishing. https:/ / doi.org/ 10.1007/ 978-3-319-63979-6 11

O berholtzer, L., Clancy, K., \& Esseks, J. K. (2010). The future of farming on the urban edge: Insights from 15 U.S. counties about farmland protection and farm viability. Journal of A griculture, F ood Systems, and C ommunity D evelopment, 1(2), 59- 75. https:// doi.org/ 10.5304/ jafscd.2010.012.003

Robertson, G. P., Allen, V. G., Boody, G., Boose, E. R., Creamer, N. G., Drinkwater, L. E., ... Wall, D. H. (2008). Long-term agricultural research: A research, education, and extension imperative. BioScienœ, 58(7), 640-645. https:// doi.org/ 10.1641/ B580711

Salant, P., Smale, M., \& Saupe, W. (1986). Farm viability: Results of the U SD A F amily Farm Surveys (Rural Development Research Report No. 60). Washington, D C: U.S. D epartment of Agriculture, Agriculture and Rural Economics Division, Economic Research Service. Retrieved from https:/ / naldc.nal.usda.gov/ download/ CAT10848524/ PDF

San Juan County. (2005). San Juan County Resolution No. 56-2005. Resolution establishing a San Juan County Agricultural Resources Committee. Retrieved from http:// www.sanjuanco.com/ documentcenter/ view/ 3784/

San Juan County Food Hub Project Team. (2016). San Juan C ounty food hub feasibility study: Coordinating sales and distribution of food grown in the San Juan Islands, W ashington. Retrieved from http:/ / sjiagguild.com/ wp-content/ uploads/ 2018/ 01/ SJC-Food-Hub-Feasibility-Study-9.22.2016.pdf 
San Juan Islands Conservation D istrict. (2016a). Overall VSP goals and benchmarks flowchart draft. Retrieved from https:/ / static1.squarespace.com/ static/ 57732786f5e231100a586a29/ t/ 577822846a49632d6e746372/ 146749094894 5/ O verall-VSP-G oals-and-Benchmarks-Flowchart-4.22.16-D RAFT.pdf

San Juan Islands Conservation D istrict. (2016b). VSP homework responses. Retrieved from https:/ / static1.squarespace.com/ static/ 57732786f5e231100a586a29/ t/ 5778226d6a49632d6e7462f5/ 146749092613 7/ VSP-Compiled-Feedback-4.25.16.pdf

San Juan County Voluntary Stewardship Program. (2018). San Juan C ounty V oluntary Stewardship Program. Retrieved from https:/ / www.sanjuanislandscd.org/ s/ Approved-VSP-Work-Plan-11218.pdf

Savickiene, J., Miceikiene, A., \& Jurgelaitiene, L. (2015, O ctober 29). A ssessment of economic viability in agriculture. Presentation at the Strategica International Academic Conference, Bucharest, Romania.

Scott, J. (2003). Farm and community viability: Report on interview results. Retrieved from http:/ / gpiatlantic.org/ pdf/ agniculture/ farmviab.pdf

Smale, M., Saupe, W. E., \& Salant, P. (1986). Farm family characteristics and the viability of farm households in Wisconsin, Mississippi, and Tennessee. A gricultural E conomics R esearch, 38(2), 11-27. http:/ / ageconsearch.umn.edu/ record/ 149313/ files/3Smale 38 2.pdf

Sorensen, A. A., Freedgood, J., D empsey, J., \& Theobald, D ., M. (2018). Farms U nder Threat: The State of A merica's Farmland. American Farmland Trust. Retrieved from https:// www.farmlandinfo.org/ sites/default/ files/AFT Farms_Under Threat_May2018\%20maps\%20B_0.pdf

Steering Committee of the San Juan County Agricultural Strategic Action Plan. (2011). G rowing our future: A n agricultural strategic adtion plan for San Juan County, W ashington. Agricultural Resources Committee of SJC, SJC WSU Extension, SJC Land Bank, San Juan Preservation Trust. PD F in possession of the corresponding author.

Thilmany McFadden, D ., Conner, D., D eller, S., Hughes, D., Meter, K., Morales, A.,... Tropp, D . (2016). The economics of local food systems: A toolkit to guide community discussions, assessments, and choios. U.S. D epartment of Agriculture, Agricultural Marketing Service. Retrieved from https:// www.ams.usda.gov/ publications/ content/ economics-localfood-systems-toolkit-guide-community-discussions-assessments

U.S. Census Bureau. (2010). L and area and persons per square mile [D ata file]. Retrieved from http:/ / www2.census.gov/ prod2/ statcomp/ usac/ excel/ LND 01.xls

U.S. D epartment of Agriculture, National Agricultural Statistics Service (USD A NASS). (2016). C ropscape - C ropland data layer San Juan County. Retrieved from https:/ / nassgeodata.gmu.edu/ CropScape/

Washington State Conservation Commission. (2016a). V oluntary Stewardship Program: A griaultural viability. Retrieved from http:/ / scc.wa.gov/ wp-content/ uploads/2016/ 09/ WSCC-Ag-Viability-paper.final_draft .pdf

Washington State Conservation Commission. (2016b). A grialtural V iability T oolkit. Retrieved from http:/ / scc.wa.gov/ wp-content/ uploads/ 2016/ 11/ Agricultural-Viability-Toolkit-VSP-final.pdf

William D . Ruckelshaus Center, The. (2007). Preserving agricultural viability and protecting critical areas: Substitute Senate Bill 5248 Progress Report N 0. N 0. 1. Washington State University and University of Washington. Retrieved from https:/ / s3.wp.wsu.edu/ uploads/ sites/ 2180/ 2013/ 06/ SSB5248Report12.01.07.FINAL .pdf

William D . Ruckelshaus Center, The. (2008). Preserving agricultural viability and protecting critical areas: Substitute Senate Bill 5248 Progress Report N 0. N 0. 2. Washington State University and University of Washington. Retrieved from https:/ / s3.wp.wsu.edu/ uploads/ sites/2180/ 2013/ 06/ ReportFinal12.10.08.pdf

William D . Ruckelshaus Center, The. (2010). A framework for stewardship: Final report of the W illiam D . Rudk elshaus C enter on the work of the A griaulture and C ritical A reas Committee. Washington State University and University of Washington. Retrieved from https:/ / s3.wp.wsu.edu/ uploads/ sites/2180/ 2013/ 06/_Ag_CA_Final_Report_for_web.pdf 